\title{
En ørefik
}

En arvelig sykdom kunne før være forbundet med skam. Kanskje det er derfor familien i beretningen fra Tidsskriftet nr. 11/1927 så motstrebende ville gi opplysninger om sykdommer i slekten? Både kvinner og menn var rammet, og i artikkelen gjengis sykehistorien til tre mannlige familiemedlemmer (utelatt her). Gitt datidens disiplineringsmetoder er det ikke godt å si om det var kraften i slaget eller beinskjørhet som var årsak til at moren brakk armen da hun fiket til en av sønnene. Det fikk følger - «al avstraffelse maatte i regelen utstaa til farens gjenkomst» (Tidsskr Nor Lægeforen 1927; 47: 557-61).

\section{Fra Ullevaal sykehus kirurg. avd. III (overlage Hj. Schilling). Nogen tilfalder av osteopsatyrosis idipathica med nedarvning i 4 led.} Av Stein F. Holst.

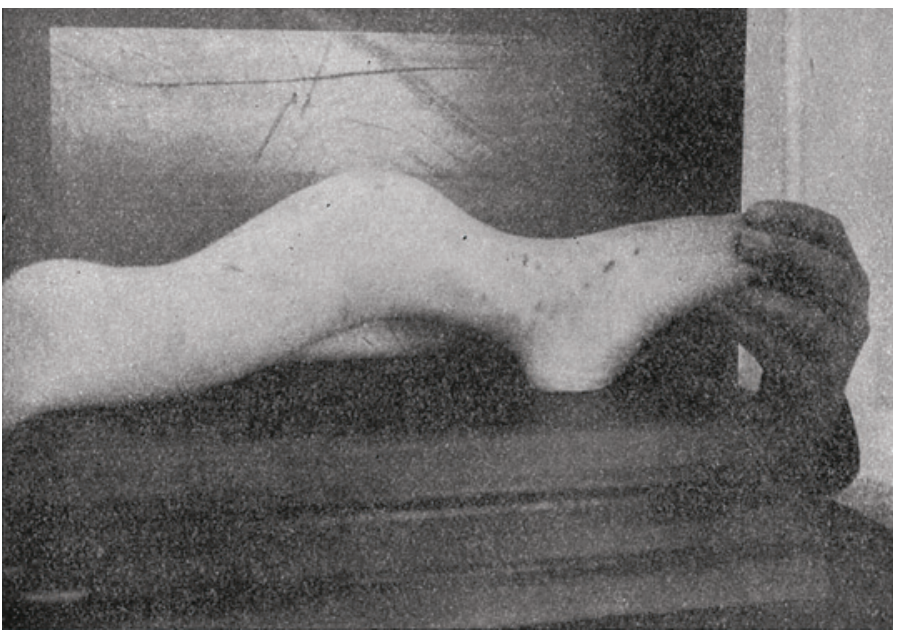

De nedenstaaende oplysninger om sygdommens optræden i samme slegt er ufuldstændige. Aarsaken hertil er familiens uvillighet til at gi oplysninger om sygdommen. Om «arvelighet» vil de spesielt ikke høre tale.

De 2 brødre, som har ligget i avd. III paa grund av benskjørhet, tilhører en søskendflok paa 18. -12 er døde av ukjendt aarsak. Av de 6 gjenlevende søskend har en søster (f. 1902) hat et brudd av ankelen for 6 aar siden. 2 brødre og en anden gift søster er friske.

Den gifte søster har 3 barn, hvorav 2 er friske ; men den yngste lider av uttalt benskjørhet.

Brødrenes far er frisk. Moren har en gang brukket underarmen, da hun fiket til en av gutterne. Al avstraffelse maatte i regelen utstaa til farens gjenkomst.

Morbror og mormor brak armer og ben mange ganger. - Sygdommen har altsaa ialdfald optraadt i 4 generationer.

Ved reparationsprocessen av de talrike brudd dannes kallus paa vanlig maate. Kalken slaar sig imidlertid ogsaa sparsomt ned i det

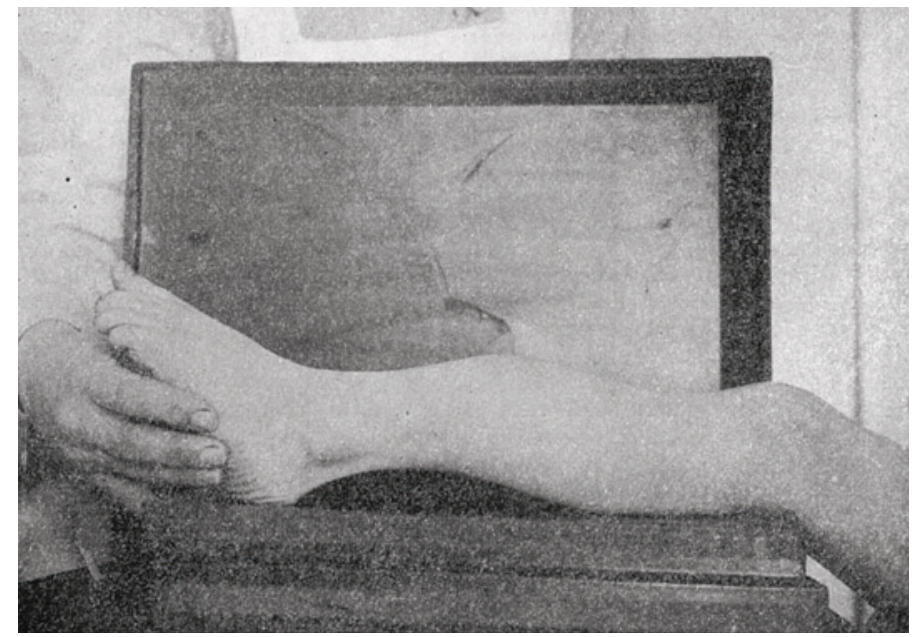

nydannede benvæv. Tilhelingstiden er noget øket, særlig ved ekstremitetsbrudd av uheldig form.

Naar en del av bruddene heler raskt, er sammenhængen den, at de lette traumer, som er tilstrækkelige til at fremkalde brudd av de skjøre ben, ikke fremkalder stor primær dislokation av bruddenderne. Patienten faar ogsaa ofte anledning til at bremse av den frakturerende kraft, før der kommer væsentlig forskyvning.

Hos 2 av patienterne er leddene løse og slængete. Abnorme bevægelser blir paa denne maate mulige. Hos «slangemennesket» blev dog leddene stivere med alderen, saa han maatte opgi sin løpebane som artist. Noget virksomt middel mot grundsygdommen har man ikke. Forgjæves har ogsaa vore patienter forsøkt kalk og fosfortran.

Hos nr. 2 av brødrene har dr. med. H a r a ld S a lv e s e n utført en bestemmelse av kalcium og fosfor i blodet. Resultatet var: Kalcium 10,4 mg. pr. $100 \mathrm{~cm} .{ }^{3}$, anorg. fosfor $4,2 \mathrm{mg}$. pr. cm. ${ }^{3}$. Begge deler ganske normale tal, som utelukker insufficiens av gl. parathyreoidea. 